\title{
Pathological study and detection of Bovine parainfluenza 3 virus in pneumonic sheep lungs using direct immunofluorescence antibody technique
}

\author{
Sameh Baghezza ${ }^{1}$ (D) $\cdot$ Bakir Mamache $^{1}$ (D) $\cdot$ Omar Bennoune $^{1}$ (D) Khireddine Ghougal $^{2}($ )
}

Received: 26 December 2020 / Accepted: 25 January 2021 / Published online: 3 February 2021

(C) Springer-Verlag London Ltd., part of Springer Nature 2021

\begin{abstract}
Bovine parainfluenza 3 virus is a common virus that causes respiratory tract infection in cattle, sheep, and goats worldwide. The objective of this study is to identify macroscopic and histopathological lung lesions in slaughtered sheep during the period from December 2018 to December 2019 and to determine the presence of Bovine parainfluenza 3 virus (BPI3V) in frozen sheep pneumonic lung using a direct immunofluorescence antibody technique (DFAT). The overall prevalence of lung affection was $11 \%$ (1440/13084). The gross lesions were acute bronchopneumonia $(58.12 \%)$, interstitial pneumonia (07.15\%), fibrinous bronchopneumonia $(10.70 \%)$, suppurative bronchopneumonia $(03.47 \%)$, verminous pneumonia $(13.75 \%)$, and ovine pulmonary adenomatosis $(06.81 \%)$. There was a significant difference in the rate of pulmonary lesions according to the seasons of the study. The lesions were more frequently observed in autumn and winter with a rate of $34.17 \%$ and $28.05 \%$, respectively. The DFAT was carried out only on 107 pneumonic samples with interstitial pneumonia, fibrinous bronchopneumonia, and acute bronchopneumonia. The BPI3V antigens were detected in 12 samples (11.21\%). This is the first study that revealed the presence of the BPI3V in pneumonic sheep lungs in Batna region using the direct immunofluorescence antibody technique. The latter may be used for definite diagnosis when histopathological modifications in pneumonic sheep caused by this virus are difficult to distinguish from those caused by other respiratory viruses.
\end{abstract}

Keywords Anatomopathology $\cdot$ Bovine parainfluenza 3 virus $\cdot$ Immunofluorescence $\cdot$ Pneumonia $\cdot$ Sheep

\section{Introduction}

Respiratory diseases are a major health problem and economic issue in sheep-rearing countries. Economic losses are associated not only with deaths but also with condemnations, lower growths, degradation of carcasses, and costs of treatment and/ or prevention. They occur because of the interaction of many infectious agents such as viruses, bacteria, mycoplasma, fungi, and parasites, host immunity and environmental factors

Sameh Baghezza

baghezza_sameh@yahoo.fr

1 Laboratory of Environment, Health and Animal Production (LEHAP), Institute of Veterinary and Agronomic Sciences, University of Batna 1, Batna, Algeria

2 Laboratory of Health Management and Animal Production, Institute of veterinary sciences, University of Constantine 1, El-Khroub, Constantine, Algeria causing high mortality rates and economic losses (Lacasta et al. 2008).

Many animal viruses have a very sharp respiratory tropism. However, other ones such as rabies virus possess a non respiratory tropism which induces the development of pneumonia as a complication by passage of saliva into the lungs after a paralysis of the pharynx (Neamat-Allah et al. 2020).

Bovine parainfluenza 3 is an RNA virus of the family Paramyxoviridae that causes mild respiratory disease of ruminants when it is the only pathogen (Underwood et al. 2015). In combination with other pathogenic agents, BPI3V is one of the most significant respiratory pathogens in ruminants (Stevenson and Hore 1970; Lehmkuhl et al. 1985; Bechmann 1997; Alkan et al. 2000). This virus can cause pneumonia on its own but it is more generally a part of the etiological complex of enzootic pneumonia (Dungworth 1993).

The confirmative diagnosis of PI3V infection is made by virus isolation in cell culture, polymerase chain reaction (PCR), and immunohistochemical (IHC) examinations of the 
lower respiratory tract (Alkan et al. 2000; Grubor et al. 2004; Gafer et al. 2009; Forghani 2010; Intisar et al. 2010).

The only histological examination of sections stained with hematoxylin and eosin (H\&E) has been reported to be insufficient for the diagnosis, because pathological changes observed in lungs infected with Bovine parainfluenza 3 virus, Bovine respiratory syncytial virus, Bovine herpes virus type 1 , and Bovine adenovirus type 3 are similar to each other (Caswell and Williams 2007).

There are no detailed studies that employed the direct immunofluorescence antibody technique to investigate the role of BPI3V in sheep pneumonia cases in Algeria. The objective of the present study was to evaluate the prevalence and characterize the gross and histopathological pneumonic lesions and to determine the presence of BPI3V using direct fluorescent antibody technique (DFAT) on frozen pneumonic lung sections of sheep from Batna municipal slaughterhouse (Eastern Algeria).

\section{Materials and methods}

\section{Study area}

This study was carried out at Batna municipal slaughterhouse (Eastern Algeria).

Batna region is semi-arid which is characterized by cold and humid winters and hot and dry summers.

This agro-pastoral region has a potential of 56.052 cattle with 35.445 dairy cows and 1.137 .361 sheep with 638.423 ewes (DSA 2019).

\section{Samples collection}

The samples were represented by lungs of sheep that were slaughtered at Batna municipal slaughterhouse during the period from December 2018 to December 2019.

A total of 13084 lungs were examined for research of lesions. The studied animals were young, aged between 6 to 18 months, originating from farms of Batna region and its surrounding areas.

The samples taken from the affected lungs were divided into two parts: one part was fixed in $10 \%$ buffered formalin and the other part was stored at $-20^{\circ} \mathrm{C}$ until analysis.

\section{Microscopic examination}

Tissue samples taken from pneumonic lesions fixed in $10 \%$ buffered formalin were dehydrated in graded ethanol and incorporated in paraffin before sectioning. Sections of $4 \mu \mathrm{m}$ in thickness were stained with $\mathrm{H} \& \mathrm{E}$ and examined using a light microscope according to the protocol of Luna (Luna 1968).

\section{Direct fluorescent antibody technique examination}

Direct fluorescent antibody technique was employed for the detection of BPI3V using monoclonal mouse anti-PI3 FITC conjugate (Cat No: BIO 030, BioxJemelle, Belgium).

The immunofluorescence staining was performed according to the manufacturer's protocol.

Lung tissues stored at $-20^{\circ} \mathrm{C}$ were cut to obtain sections of $4 \mu \mathrm{m}$ thickness that were placed on silanized slides (SuperFrost ${ }^{\circledR}$ Plus Gold) and air-dried. At that time, the sections were fixed in ethanol for $15 \mathrm{~min}$ at room temperature. After washing in phosphate-buffered saline (PBS), the sections were treated with the conjugate diluted in a 1:20 ratio with PBS-Blue Evans at room temperature for $1 \mathrm{~h}$ in a dark place. After the second washing in PBS, the slides were mounted with glycerol. Finally, the sections obtained were examined under a fluorescent microscope.

The DFAT was only performed in tissue with interstitial pneumonia, fibrinous bronchopneumonia, and acute bronchopneumonia, because BPI3V is one of the respiratory germs incriminated in the appearance and development of these pneumonias.

\section{Statistical analysis}

Data were analyzed by Software R version 2.14.1. The Chisquare of Pearson $\left({ }_{X}^{2}\right)$ test was used to compare the rates of pneumonic lesions in different seasons of the study. The differences were considered statistically significant if the $P$-value is less than 0.05 .

\section{Results}

Pneumonia was observed in 1440 cases out of 13084 examined lungs, representing a prevalence of $11 \%$. Severity, type, and distribution of pneumonia during the seasons are summarized in Table 1.

The lesions were scored as mild or severe when they affect less than 10\%, 10-20 and more than $20 \%$ of the pulmonary tissue, respectively. Examples of the grading system are shown in (Fig. 1).

In this study, pneumonia was mild in $58.05 \%$, moderate in $30.42 \%$, and severe in $11.53 \%$ of the lungs, respectively.

Pneumonia occurred in all seasons with varying degrees but autumn and winter showed the highest rates of $34.17 \%$ (492/1440) and 28.05\% (404/1440), respectively.

The peak of occurrence of pulmonary lesions was observed during October with 267/1440 cases (18.54\%) and December with 218/1440 cases (15.14\%). The number of lung lesions was lower in February and March with 63/1440 cases $(04.37 \%)$ and $53 / 1440$ cases $(03.68 \%)$, respectively. 
Table 1 Seasonal distribution and severity of pneumonia in sheep

\begin{tabular}{|c|c|c|c|c|c|c|}
\hline & Winter $(\%)$ & Spring $(\%)$ & Summer $(\%)$ & Autumn (\%) & Total $(\%)$ & \\
\hline Number of lesions (\%) & $404(28.05)$ & $240(16.67)$ & $304(21.11)$ & $492(34.17)$ & $1440(11)$ & \\
\hline \multicolumn{7}{|l|}{ Lesion severity (score) } \\
\hline Mild & $212(25.36)$ & $135(16.15)$ & $181(21.65)$ & $308(36.84)$ & $836(58.05)$ & \\
\hline Moderate & $121(27.52)$ & $74(16.89)$ & $102(23.29)$ & $141(32.19)$ & $438(30.42)$ & \\
\hline Severe & $71(42.77)$ & $31(18.67)$ & $21(12.65)$ & $43(25.90)$ & $166(11.53)$ & \\
\hline Type of lesion & & & & & & $P$ value \\
\hline Acute bronchopneumonia & $214(25.56)$ & $147(17.57)$ & $174(20.79)$ & $302(36.08)$ & $837(58.12)$ & 0.054 \\
\hline Fibrinous bronchopneumonia & $29(18.82)$ & $18(11.69)$ & $27(17.54)$ & $80(51.95)$ & $154(10.70)$ & $0.0001 *$ \\
\hline Suppurative bronchopneumonia & $14(28)$ & 07 (14) & $21(42)$ & $08(16)$ & $50(3.47)$ & $0.001 *$ \\
\hline Interstitial pneumonia & $45(43.68)$ & $19(18.46)$ & $15(14.56)$ & $24(23.30)$ & $103(7.15)$ & $0.001 *$ \\
\hline Verminous pneumonia & $84(42.42)$ & $14(07.08)$ & $48(24.24)$ & $52(26.26)$ & $198(13.75)$ & $0.0001 *$ \\
\hline Ovine pulmonary adenomatosis & $18(18.37)$ & $35(35.71)$ & $19(19.39)$ & $26(26.53)$ & $98(6.81)$ & $0.0001 *$ \\
\hline
\end{tabular}

$P$ value statistically significant: $P<0.05$

*Significant

\section{Gross pathological investigation}

On the basis of predominant pathological findings, the lesions were further classified into acute bronchopneumonia, fibrinous bronchopneumonia, suppurative bronchopneumonia, interstitial pneumonia, verminous pneumonia, and ovine pulmonary adenomatosis.

Acute bronchopneumonia and verminous pneumonia were the most dominant lesions (Table 1).

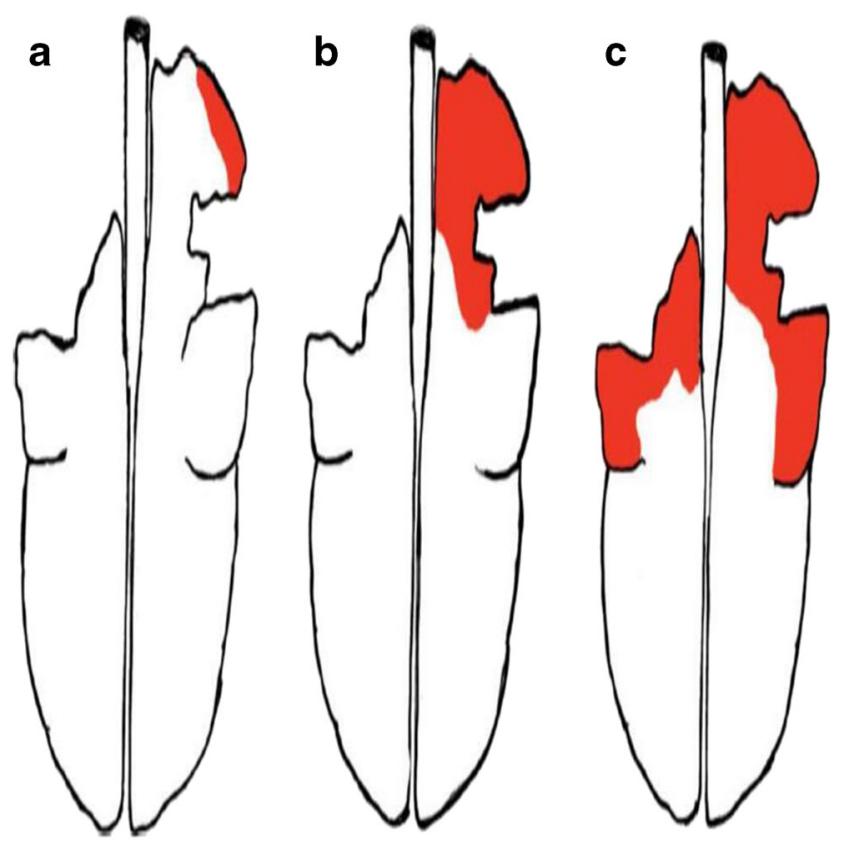

Fig. 1 Examples of the grading system of pneumonia. a Mild: less the $10 \%$ of the tissue affected. b Moderate: $10-20 \%$ of the tissue affected. c Severe: more than $20 \%$ of the tissue affected (Lindstrom et al. 2018)

\section{Acute bronchopneumonia}

This lesion was the most encountered with a rate of $58.12 \%$. The lung macroscopic aspect was characterized by solid texture, meaty consistency with dark color areas of hepatization, particularly in the apical lobes, especially the right one, reaching either part or all of the latter (Fig. 2). The affected area was clearly delimited.

The microscopic aspect was distinguished by the complete absence of alveolar lumen, thickened alveolar septa by mild macrophage infiltration and the presence of neutrophils around and inside the bronchioles (Fig. 3).

There was no association between the presence of acute bronchopneumonia and the study season $(P$-value $=0.054)$.

\section{Verminous pneumonia}

Verminous pneumonia was observed in $13.75 \%$ of the affected lungs. Macroscopically, this lesion was directly visible on the dorsal side of the lungs. There were two types of lesions associated with the parasitic species. Tiny nodules of 1-2 $\mathrm{mm}$ in diameter varied from hemorrhagic points to yellowish-gray nodules and hard or even calcified grayish yellow patches (candle spot) on the dorsal edges of the lungs, from a few $\mathrm{mm}$ to $2-3 \mathrm{~cm}$ may be seen. They had clear boundaries and rise on the surface of the lung. Their consistency is rubbery (Fig. 4). Microscopically, the alveoli contain a large number of parasitic forms (eggs and the first stage of larvae) and infiltration of inflammatory cells can be observed (Fig. 5). 


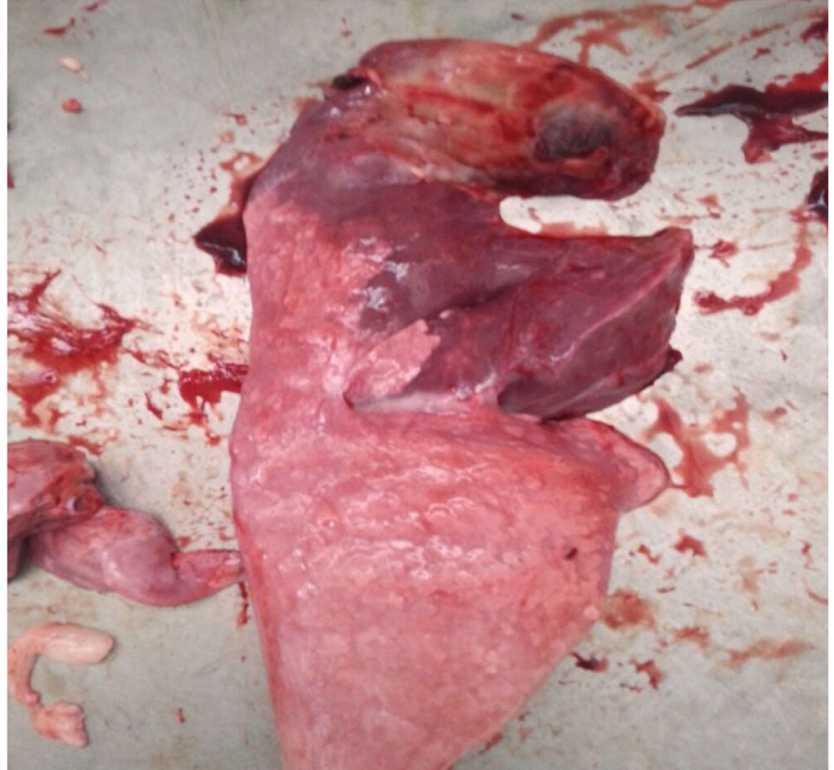

Fig. 2 Acute bronchopneumonia, characterized by the dark area affected cranial and ventral right lobes (hepatization)

\section{Fibrinous bronchopneumonia}

Fibrinous bronchopneumonia was found in $10.70 \%$ of the cases. It is characterized by the loss of elasticity of the affected pulmonary parenchyma and the lesion is surrounded by a fibrinous coating. This lesion was observed mostly in the cranial and middle lobes (Fig. 6).

Microscopic features were characterized by an exudation of fibrin and neutrophils in the bronchi, bronchioles, and the lumen of the alveoli. The interlobular septae were thickened

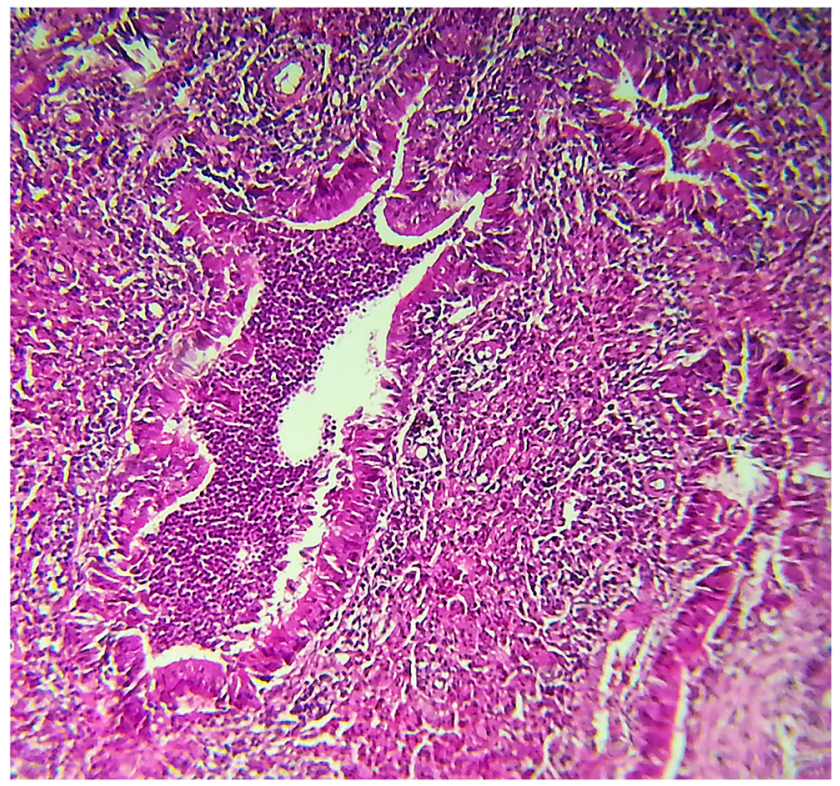

Fig. 3 Microscopically, acute bronchopneumonia showed the absence of pulmonary alveoli (atelectasis), hyperplasia of the bronchiolar epithelium, and the presence of intra-bronchial inflammatory cells $(\mathrm{H} \& \mathrm{E}) \times 100$

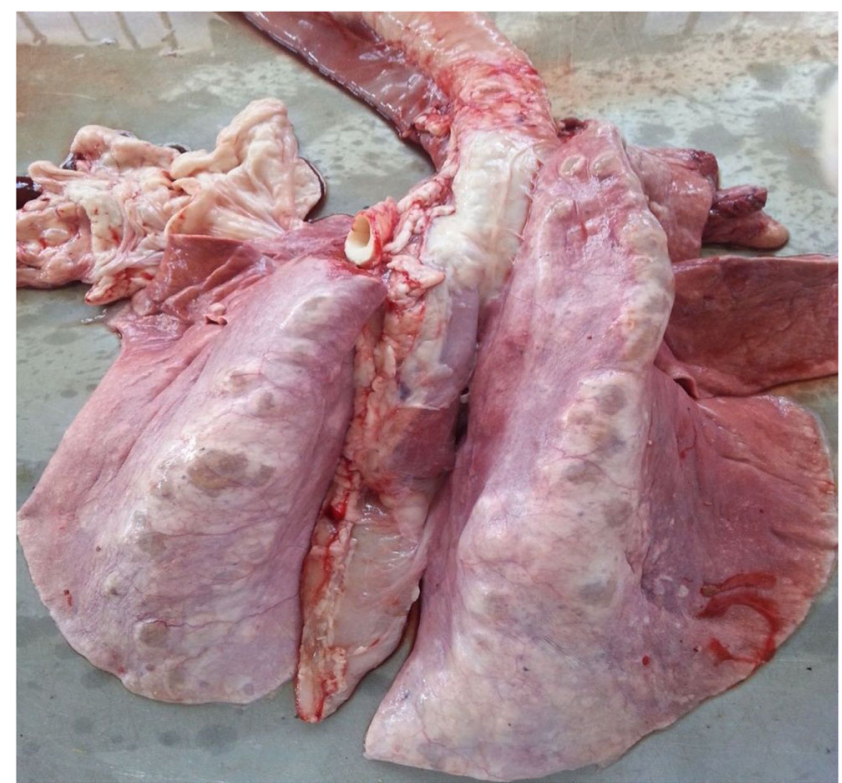

Fig. 4 Macroscopic appearance of verminous pneumonia, lobular form: characterized by the presence of lesions of a few centimeters, of hard consistency on the dorsal surface of the affected lung

by an invasion of a fibrino-cellular exudate consisting primarily of neutrophils and mononuclear cells (Fig. 7).

\section{Interstitial pneumonia}

The results showed that $7.15 \%$ of lung lesions were diagnosed as interstitial pneumonia. Unlike fibrinous bronchopneumonia in which the distribution of the lesions was typically in cranial and middle lobes, in interstitial pneumonia, most parts of the

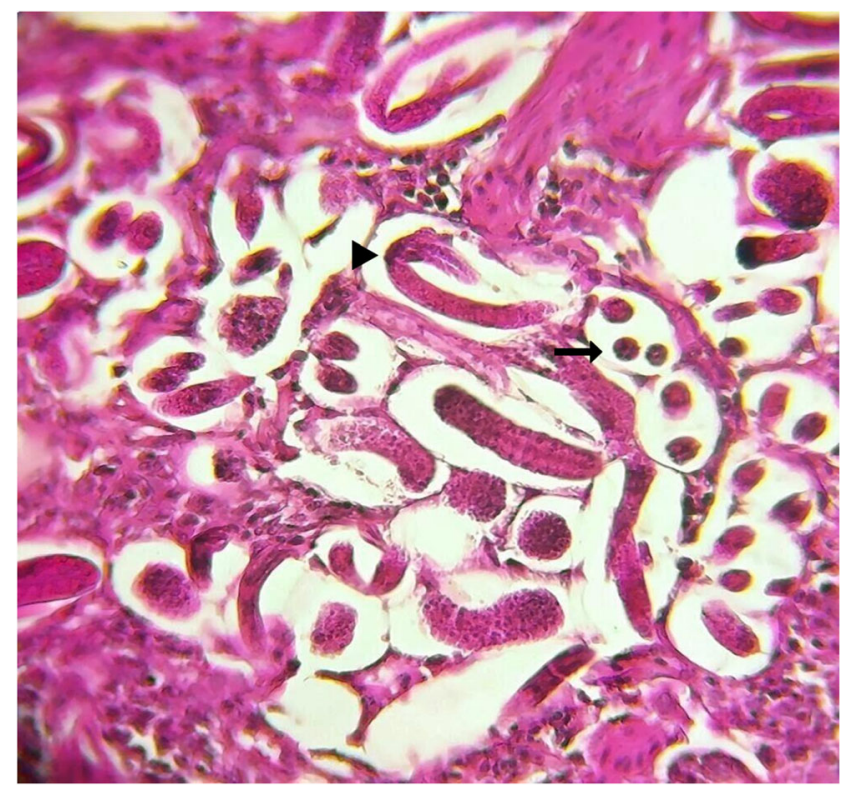

Fig. 5 Histological section of verminous pneumonia characterized by the presence of numerous larvae (black arrow head) and eggs (black arrow) in the alveolar lumen with the presence of inflammatory cells $(H \& E) \times 200$ 


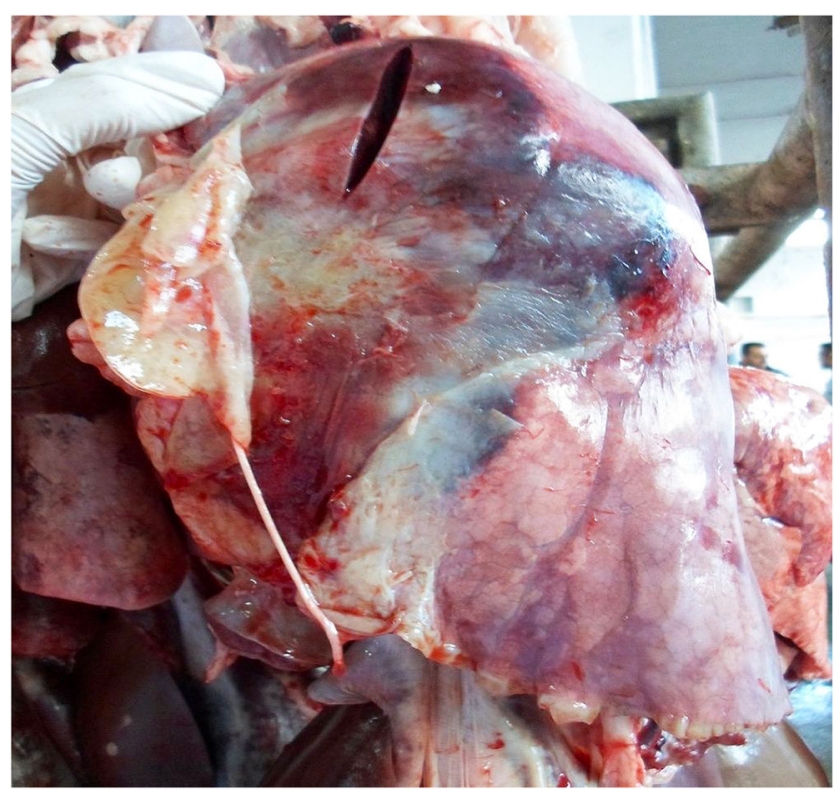

Fig. 6 Macroscopic appearance of fibrinous bronchopneumonia: the affected part is dark and rough in texture, the consolidation observed in the apical and middle lobe, surrounded by a thick layer of fibrin, the caudal part of the lung is normal

lungs were enlarged and unclasped. The lesions were distributed more diffusely and usually concern all the lobes and in some cases, they tend to be more prominent in the caudal parts of the lungs (Fig. 8). The color of the affected lungs ranges from red in acute cases to pale gray or marbled red in ancient ones.

Microscopically, the lesion is characterized by a thickening of the inter-alveolar wall due to the mononuclear cell infiltration (Fig. 9).

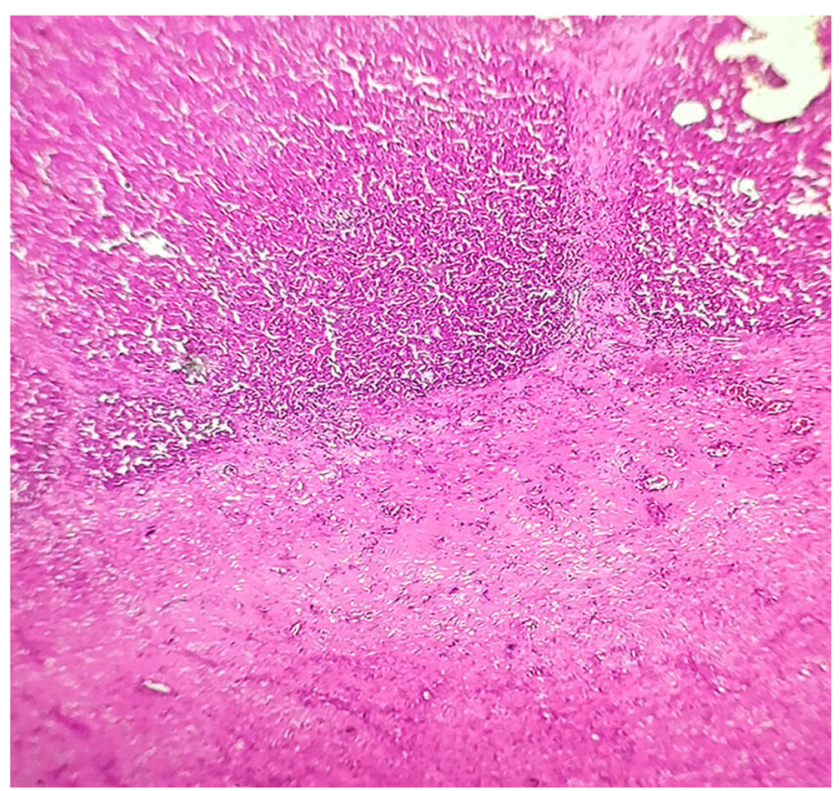

Fig. 7 Histological section of fibrinous bronchopneumonia characterized by fibrin deposition surrounded by inflammatory neutrophil cells (H\&E) $\times 100$

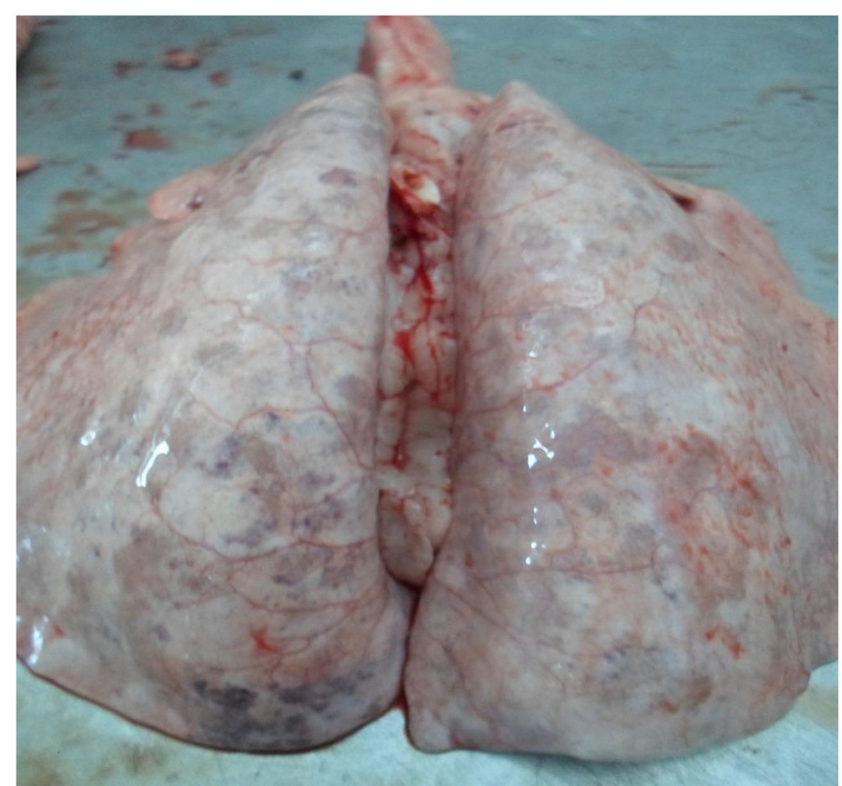

Fig. 8 Interstitial pneumonia: the lung is distended, heavy, and pale

\section{Suppurative bronchopneumonia}

Suppurative bronchopneumonia was detected in $3.47 \%$ of the pneumonic lungs. This lesion was particularly affecting the apical and middle lobes. Grossly, the consolidated area of the lungs was dark red. Abscesses of a small pea to a walnut sizes were disseminated in the lung parenchyma (Fig. 10). The incision was accompanied by a flow of necrotic material. Microscopically, inflammatory exudates and cells mostly neutrophils filled the lumens of the airways and alveolar spaces.

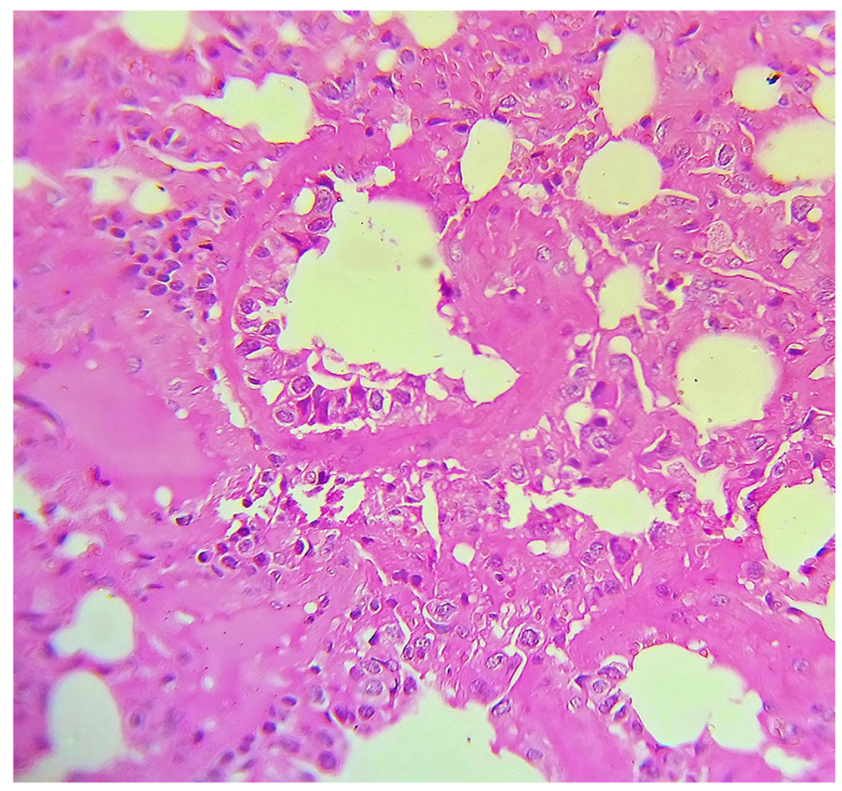

Fig. 9 A section of interstitial pneumonia showing the thickening of alveolar septa by severe interstitial infiltration of inflammatory cells, alveolar lumen filled with fluid (edema) $(\mathrm{H} \& \mathrm{E}) \times 100$ 


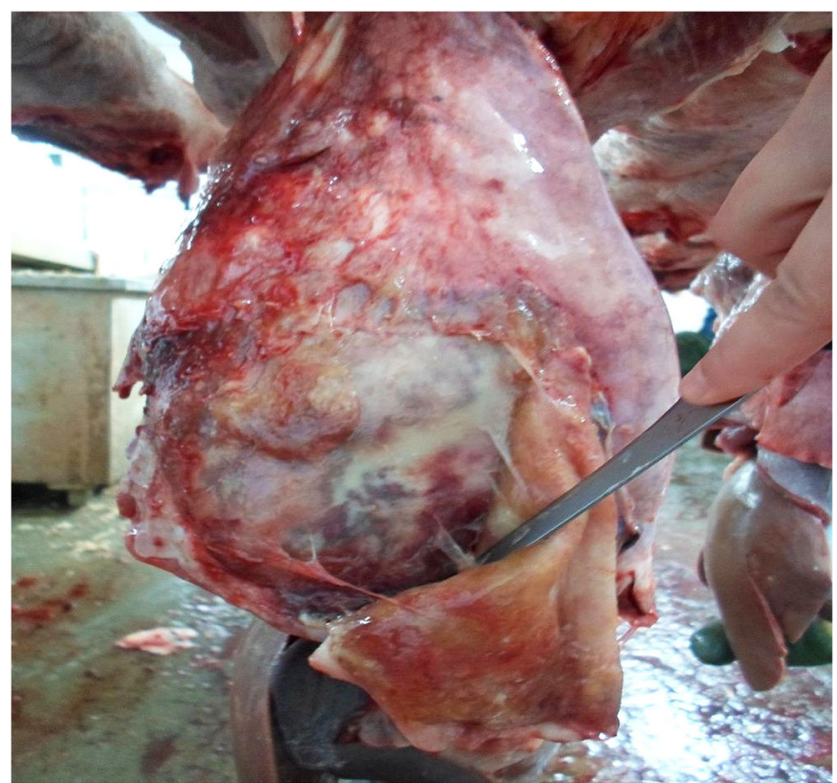

Fig. 10 Suppurative bronchopneumonia is characterized by the involvement of the apical and middle lobes, the presence of purulent exudates in the bronchi

Multifocal necrosis areas surrounded by a pyogenic membrane were observed (Fig. 11).

\section{Ovine pulmonary adenomatosis}

Ovine pulmonary adenomatosis was detected in $6.81 \%$ of the lungs. The classic type of pulmonary adenomatosis is the most frequently seen and it results in a swelling of the lung with loss of elasticity. The lungs were thicker, distended, and rigid, with

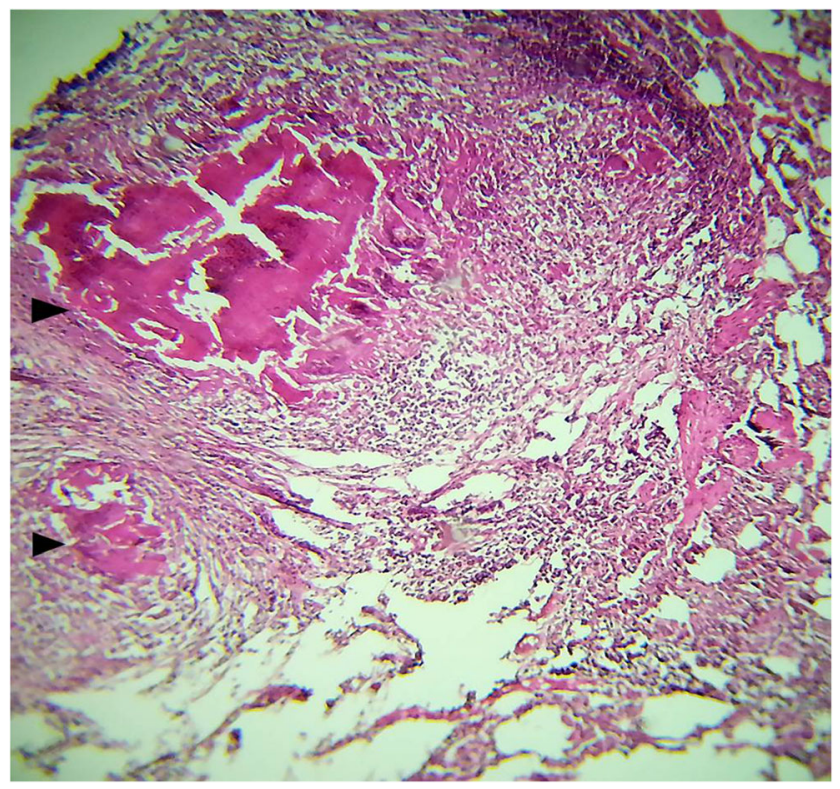

Fig. 11 Microscopically suppurative bronchopneumonia showing a necrotic tissue (black arrow head) and the presence of inflammatory cells around the necrotic tissue $(\mathrm{H} \& \mathrm{E}) \times 100$ the presence of large hard masses in different lobes (tumoral form) (Fig. 12). On cross-section, important volumes of mucoid secretion were seen under the action of low pressure. A white spumosity was often observed in the trachea and bronchi.

Microscopically, this lesion had a papillomatous proliferation; mainly of type II pneumocytes and secretory epithelial cells in the pulmonary alveoli. Unciliated cells (Clara cells) and epithelial cells of terminal bronchioles may be involved (Fig. 13).

The Chi-square test showed that there was a statistically significant association between the presence of the pulmonary lesions in sheep (fibrinous bronchopneumonia, interstitial pneumonia, suppurative bronchopneumonia, verminous pneumonia, and OPA) and the season of study, and it was highly significant for verminous pneumonia, ovine pulmonary adenomatosis, and fibrinous bronchopneumonia (Table 1).

\section{Results of the direct fluorescent antibody test}

This study describes, for the first time, the detection of BPI3V in pneumonic sheep lungs using the direct immunofluorescence test.

One hundred and seven pieces of sheep pneumonic lungs were treated by the conjugate of DFAT. Bovine parainfluenza 3 virus was detected in 12 pneumonic samples representing a rate of $11.21 \%$ (Table 2).

The fluorescence staining was detected in the epithelium of alveoli and bronchioles. The fluorescence reactions had varying sizes and sometimes granular appearance (Fig. 14a, Fig. 14b).

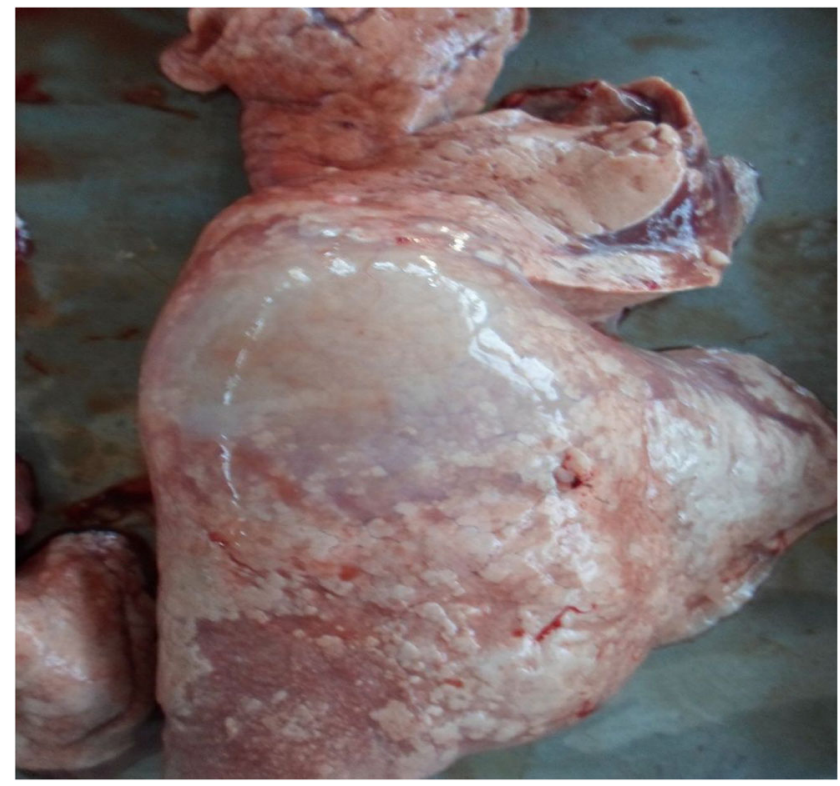

Fig. 12 Pulmonary adenomatosis: the lung reaches is heavy, distended with the presence of hard, pale-colored masses of varied sizes (tumor mass) 


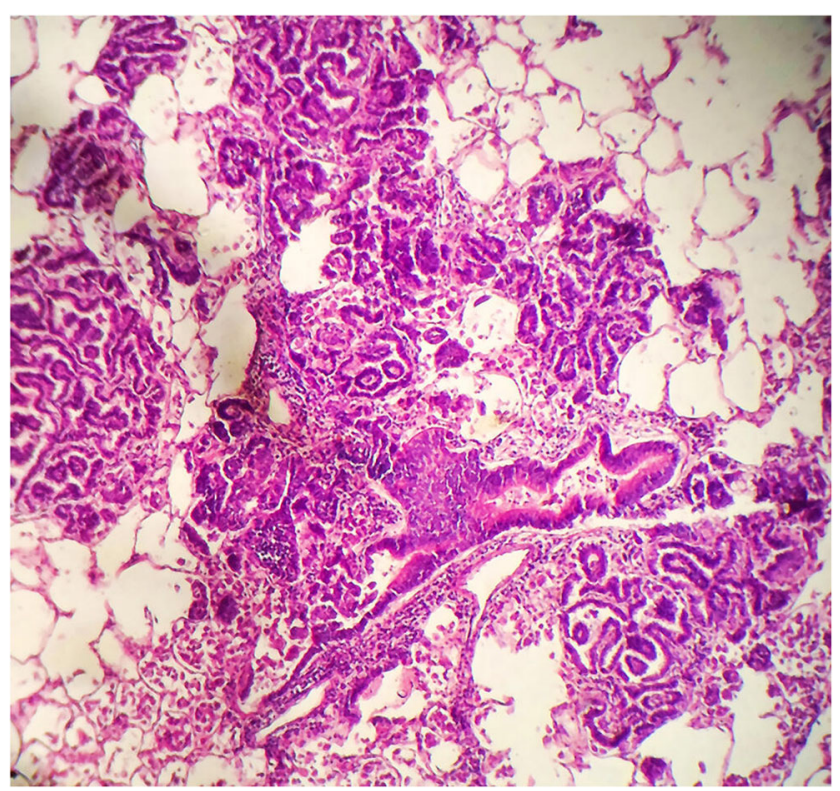

Fig. 13 Histological adenomatosis section showing a neoplastic proliferation of pneumocytes type II, surrounded by normal-looking alveoli $(\mathrm{H} \& \mathrm{E}) \times 100$

Lesions found positive for bovine parainfluenza virus 3 using the direct immunofluorescence technique were characterized histologically by atelectasis, thickening of interalveolar septae, fibrosis, hyperplasia of bronchi and bronchiolar epithelium with peribronchial and peribronchiolar inflammatory cell infiltrations, and lymphoid hyperplasia (Table 3).

\section{Discussion}

Pneumonia is widespread among sheep and goats worldwide and is considered one of the major causes of failure in the small ruminant industry (Mohamed and Abdelsalam 2008; Hala et al. 2009) and a limiting factor of the development of animal production (Attoh-kotoku et al. 2018).

The present study had revealed that $11 \%(1440 / 13084)$ of male sheep had pneumonia. This prevalence is lower than that reported by previous studies (Kumar et al. 2014; Mahdi et al. 2015; Mekibib et al. 2019; Hashemnia et al. 2019; Baghezza

Table 2 Detection of BPI3V antigens in cases of pneumonic lesions using DFAT

\begin{tabular}{lll}
\hline Type of lesion & $\begin{array}{l}\text { Number of lung } \\
\text { tested }\end{array}$ & $\begin{array}{l}\text { Number of positive } \\
(\%)\end{array}$ \\
\hline $\begin{array}{l}\text { Acute bronchopneumonia } \\
\text { Fibrinous }\end{array}$ & 57 & $7(12.28)$ \\
bronchopneumonia & 32 & $2(6.25)$ \\
$\begin{array}{l}\text { Interstitial pneumonia } \\
\text { Total }\end{array}$ & 18 & $3(16.66)$ \\
\end{tabular}
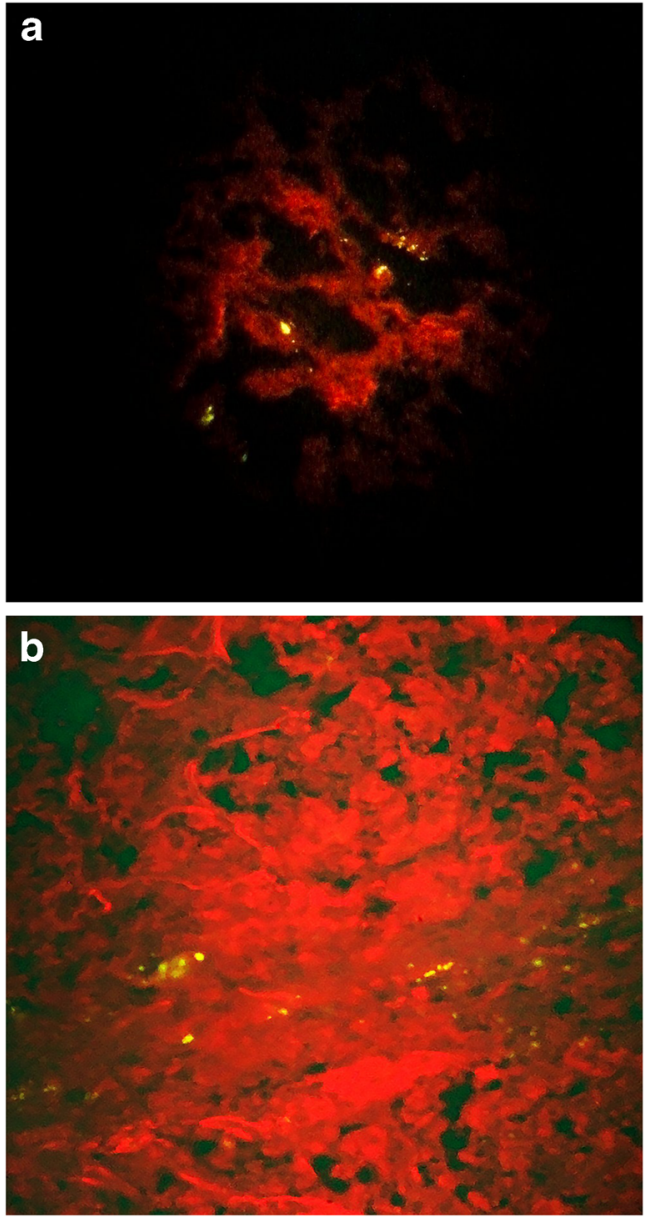

Fig.14 a Immunofluorescence staining of the frozen-cut lung tissue, DFAT positivity in the alveolar epithelium $(\times 40)$. b Granular green fluorescence in the alveolar epithelium by DFAT $(\times 100)$

et al. 2019) and higher than other ones (Azizi et al. 2013; Mugale and Balachandran 2019; Emikpe et al. 2019).

The lungs are the most vulnerable organs to multiple aggressions because of their anatomical and histological particularities (Caswell and Williams 2007; Dar et al. 2013). Many factors such as age, geographic location, nutrition, and environment are determining factors on the type of microorganism which causes respiratory diseases. In addition, rearing processes, stress factors, climate change, and unhygienic conditions, sudden changes in feed and low level of herd health status are identified as predisposing factors to infection (Azizi et al. 2013).

In the present study, acute bronchopneumonia was found in $58.18 \%$. A much lower occurrence of this lesion was observed in previous studies (Dar et al. 2014; Singh et al. 2017; Mishra et al. 2018; Hashemnia et al. 2019; Kumar et al. 2014).

Verminous pneumonia ranked in the second place with a rate of $13.75 \%$. This finding was much higher than the results reported in Iran (Borji et al. 2012; Mishra et al. 2018; Hashemnia et al. 2019) and India (Dar et al. 2013). However, this rate was lower than that obtained in Ethiopia (Kassahun 
Table 3 Histopathological characterization of BPI3Vpositive sheep pneumonic lungs

\begin{tabular}{lllll}
\hline Lesions & $\begin{array}{l}\text { Acute } \\
\text { bronchopneumonia }\end{array}$ & $\begin{array}{l}\text { Fibrinous } \\
\text { bronchopneumonia }\end{array}$ & $\begin{array}{l}\text { Interstitial } \\
\text { pneumonia }\end{array}$ & Total (\%) \\
\hline $\begin{array}{l}\text { Hyperplasia of bronchi and } \\
\text { bronchiolar epithelium }\end{array}$ & $5 / 7$ & $2 / 2$ & $0 / 3$ & $7 / 12(58.33)$ \\
$\begin{array}{l}\text { Thickening of the inter-alveolar } \\
\quad \text { septa }\end{array}$ & $2 / 7$ & $0 / 2$ & $1 / 3$ & $3 / 12(25)$ \\
$\begin{array}{l}\text { Atelectasis } \\
\text { Lymphoid hyperplasia }\end{array}$ & $7 / 7$ & $2 / 2$ & $0 / 3$ & $9 / 12(75)$ \\
Inflammatorycell infiltration & $4 / 7$ & $1 / 2$ & $0 / 3$ & $4 / 12(33.33)$ \\
Intra-alveolar edema & $0 / 7$ & $1 / 2$ & $1 / 3$ & $6 / 12(50)$ \\
\hline
\end{tabular}

and Mersha 2013) and in Eastern Algeria (Kayoueche 2009), where verminous pneumonia reached rates of $57.55 \%$ and $44.43 \%$, respectively.

The difference in the rate of verminous pneumonia in our research and the studies cited thereafter could be attributed to the following reasons: the immune status of each sheep; alveolar macrophages, eosinophils, neutrophils, and lymphocytes could play a significant role in pulmonary resistance to protostrongles. The animals' nutritional status, management practices, climate, humidity, and temperature are also factors that promote the parasite cycle and the growth and survival of the intermediate host (Berrag and Cabaret 1996; Addis et al. 2011). Furthermore, the frequency of verminous pneumonia may be explained, in part, by the difficulty in monitoring the populations of snails or slugs that serve as intermediate hosts in these parasites' indirect life cycles (Hashemnia et al. 2019).

Fibrinous bronchopneumonia was detected in 154 cases $(10.70 \%)$ and this finding was higher than the result mentioned in other studies (Kumar et al. 2014; Mishra et al. 2018). However, such a result was lower than the rates recorded in Iraq (Mahdi et al. 2015) and in Ethiopia (Mekibib et al. 2019) where fibrinous bronchopneumonia was reported in $15 \%$ and $19 \%$, respectively. This result was close to that obtained in previous works with $11.67 \%$, and $11.1 \%$, respectively (Dar et al. 2014; Singh et al. 2017).

One hundred and three out of 1440 cases revealed interstitial pneumonia with a rate of $7.15 \%$. The observed lesions were similar to those mentioned in earlier study (Dar et al. 2014). However, the obtained rate was lower than that reported by other researchers (Mishra et al. 2018; Hashemnia et al. 2019).

Stress factors may alter the immune system function and render the animal more vulnerable to develop pneumonia (Martin 1996; Brogden et al. 1998).

Suppurative bronchopneumonia was detected only on 50 occasions $(3.47 \%)$. This finding was lower than that found in a previous research works, where this lesion was observed at a rate of $12.84 \%, 20 \%$, and $17.9 \%$, respectively (Dar et al. 2014; Mahdi et al. 2015; Mekibib et al. 2019).

Ovine pulmonary adenomatosis was found in $6.81 \%$ of pneumonic sheep lungs. Such a result was higher than those reported in previous studies (Mishra et al. 2018; Singh et al. 2018; Mekibib et al. 2019; Hashemnia et al. 2019).

Ovine pulmonary adenocarcinoma is a neoplasia of ovine lungs caused by the Jaagsiekte sheep retrovirus (JSRV). It has been described in sheep worldwide, except in Australia. Its incidence is high in South Africa, Scotland, and Peru, but in North America it is unknown but it is probably low (Lopez and Martinson 2017).

There is a significant difference between the rates of interstitial pneumonia, fibrinous bronchopneumonia, suppurative bronchopneumonia, and pulmonary adenomatosis according to the seasons of study; this can be explained by the fact that climate change is a favoring factor for the multiplication and manifestation of respiratory germs in the affected animal, which leads to a decrease in the defenses of the respiratory system and leads to the appearance and development of pneumonia.

In laboratories with few technical resources, diagnostic methods such as direct or indirect immunofluorescence and immunoperoxidase tests can be used as alternative methods because they are quick, simple, sensitive, and specific, and allow an efficient diagnosis of viral diseases (Dennet et al. 1976; Ahmed et al. 1999).

This study describes for the first time the direct immunofluorescence detection of BPI3V antigens in pneumonic sheep lungs slaughtered at municipal slaughter house of Batna. The antigens were detected in 12 out of 107 pneumonic lesions, showing a prevalence of $11.21 \%$ (Table 2 ).

This finding is in accordance with prevalence detected in cattle pneumonia in Turkey (10.53\%) (Ceribasi et al. 2014) However, our finding was lower than the result observed on pneumonic caprine lungs in Turkey and pneumonic lesions of cattle in Sudan with a rate of $44.40 \%$ and $25 \%$, respectively (Ceribasi et al. 2012; Noori et al. 2014).

Specific fluorescence, showing the presence of BPI3V, was detected in the surrounding alveoli and in the epithelium of the bronchioles. Foci of fluorescence were most commonly observed in these sites, indicating that the initial histopathological changes occur in lambs experimentally infected with the PI3 virus (Stevenson and Hore 1970). In previous works, the 
DFAT has successfully been used as a rapid diagnostic method for the research of PI3V (Gafer et al. 2009; Ceribasi et al. 2012; Ceribasi et al. 2014; Anita et al. 2015). These findings are in accordance with those obtained by Ceribasi et al. (2014) where it was demonstrated that specific DFAT stainings for viral antigen in the pneumonic cattle lungs were intensively detected in the bronchiolar epithelium and less frequently in the alveolar epithelium as the size ranged from small to large homogeneous granular masses.

In the present study, the histopathological findings in BPI3V-positive pneumonic sheep lungs were similar to those described in pneumonic caprine lungs (Ceribasi et al. 2012; Anita et al. 2015; Kamdi et al. 2020).

The pathogenic function of PI3V in sheep is close to that in cattle (Dungworth 1993). The Bovine parainfluenza 3 virus inhibits the function of alveolar macrophages and destroys cilia on the bronchial mucosa. This reduces the animal's normal clearance process for the elimination of pathogens from the respiratory tract and makes it more vulnerable to secondary bacterial infections (Yener et al. 2005).

DFAT is a beneficial technique in terms of achieving rapid results since the preparation and examination of the samples is achieved within a short time (Edwards et al. 1988; Forghani 2010). However, FAT is an inadequate technique to recognize appropriate morphological details in tissues (Stevenson 1969; Kahrs 1981). Even though preparing of formalin-fixed tissues needs more time, retrospective microscopic findings showed that formalin-fixed sections are superior to frozen sections in terms of accurate cell and tissue identification. However, immunogenic epitopes and many antisera used for immunohistochemistry diagnosis are unreactive in fixed specimens due to the damaging effect of fixation (Haines and Chelack 1991).

\section{Conclusion}

In conclusion, the postmortem examination had shown the presence of lung lesions in slaughtered sheep. The present study describes for the first time the presence of BPI3V at a rate of $11.21 \%$ by DFAT in pneumonic sheep lungs slaughtered at Batna municipal slaughterhouse. It is possible to conclude that BPI3V might have an essential role in the pathogenesis of pneumonia in sheep of the study region. DFAT may be used for definite diagnosis when histopathological modifications caused by BPI3V are difficult to differentiate from those induced by other ovine respiratory viruses.

Acknowledgments The authors would like to express their special thanks to the staff members of Batna municipal slaughterhouse for all sorts of assistance and management for allowing us to conduct postmortem inspection on visceral organs of slaughtered animals. The authors are indebted to the staff of the Laboratory of Anatomopathology of the University Teaching Hospital Mustapha Pacha Algiers, Algeria, especially Professor Amir and Engineer Bouchemla for their assistance. We would like to thank Dr. Kadri for her help in the Laboratory of Histology of the Institute of Veterinary and Agronomic Sciences, University Hadj Lakhdar Batna-1, Algeria.

\section{Declarations}

Ethical approval All applicable international, national, and/or institutional guidelines for the care and use of animals were followed. This article does not contain any studies with human participants performed by any of the authors.

Conflict of interest The authors declare that they have no conflict of interest.

\section{References}

Addis M, Fromas A, Ebuy Y (2011) Study of the prevalence of lungworm infection in small ruminants in Gondar Town. Ethiopia J anim Vet Adv 10:1683-1687

Ahmed I, Hameed A, Memon M, Naeem K (1999) Seroprevalence of bovine herpesvirus 1 among cattle and buffaloes in Pakistan. Pak Vet J 19:60-63

Alkan F, Ozkul A, Bilge-Dagalp S, Yesilbag K, Oguzoglu TC, Akca Y, Burgu I (2000) Virological and serological studies on the role of PI3 virus, BRSV, BVDV and BHV-1 on respiratory infections of cattle. I. The detection of etiological agents by direct immunofluorescence technique. Dtsch Tierarztl Wochenschr 107:193-195

Anita A, Anita D, Raileanu C, Savuta G (2015) Detection of parainfluenza type 3 virus antigens in goats. Bulletin of University of Agricultural Sciences and Veterinary Medicin Cluj-Napoca. Vet Med 72(1):27-29. https://doi.org/10.15835/buasvmen-vm:10385

Attoh-Kotoku V, Emikpe VB, Obuadey D (2018) Patterns and direct financial implications of contagious pleuropneumonia in cattle slaughtered in Kumasi Abattoir, Ghana. Anim Res Int 15:2937-2943

Azizi S, Shahrani Korani F, Oryan A (2013) Pneumonia in slaughtered sheep in South-Western Iran: pathological characteristics and aerobic bacterial aetiology. Vet Ital 49:109-118

Baghezza S, Mamache B, Belkhiri M, Bennoune O, Djabaa S (2019) Anatomo-pathological study of lung lesions in slaughtered sheep at Batna municipal Slaughterhouse (Eastern Algeria). Comp Clin Pathol 29(1):247-254. https://doi.org/10.1007/s00580-019-03050-6

Bechmann G (1997) Serological investigations in the diagnosis of viral infections derived from cattle in sheep. Dtsch Tierarztl Wochenschr 104:321-324

Berrag B, Cabaret J (1996) Impaired pulmonary gas exchange in ewes naturally infected by small lungworms. Int J Parasitol 26:1397-1400

Borji H, Azizzadeh M, Ebrahimi M, Asadpour M (2012) Study on small ruminant-associated risk lungworms and factoring in northeastern Iran. Asian Pac J Trop Dis 5:853-856

Brogden KA, Lehmkuhl HD, Cutlip RC (1998) Pasteurella haemolytica complicated respiratory infections in sheep and goats. Vet Res 29:233-254

Caswell JL, Williams K (2007) The respiratory system. In: Jubb KVF, Kennedy PC, Palmer N, Maxie MG (eds) Pathology of domestic animals, 5th edn. Saunders Elsevier, Edinburgh, UK, pp 524-650

Ceribasi S, Ozkaraca M, Ozer H, Çeribasi AO (2012) Prevalence of parainfluenza type 3-virus antigens innpneumonic caprine lungs by direct immunofluorescence and immunoperoxidase techniques. Small Rumin Res 108:127-132

Ceribasi AO, Ozkaraca M, Ceribasi S, Ozer H (2014) Histopathologic, immunoperoxidase and immunofluorescent examinations on natural cattle pneumonia originated from Parainfluenza type 3, Respiratory Syncytial virus, Adenovirus type 3 and Herpesvirus type 1. Rev Med Vet 165:201-212 
Dar LM, Darzi MM, Mir MS, Kamil SA, Rashid A, Abdullah S (2013) Prevalence of lung affections in sheep in northern temperate regions of India: a postmortem study. Small Rumin Res 110:57-61

Dar LM, Darzi MM, Mir MS, Kamil SA, Rashid A, Abdullah S, Hussain SA, Rather FA, Parihar S (2014) Histopathological and histoenzymatic studies on bronchopneumonia in sheep. J Appl Anim Res 42:289-296. https://doi.org/10.1080/09712119.2013.845101

Dennet DP, Barasa JQ, Johnson JH (1976) Infectious bovine rhinotracheitis virus: studies on the venereal carrier status range of cattle. Res Vet Sci 20:77-83

DSA (2019) Direction des Services Agricole de la Wilaya de Batna. Services Statistiques

Dungworth DL (1993) Respiratory system. In: Jubb KVF, Kennedy PC, Palmer N (eds) Pathology of domestic animals, 4th edn. Academic Press, Inc, San Diego, CA, pp 613-615

Edwards S, White H, Newman RH, Nixon P (1988) A veterinary services scheme for the rapid diagnosis of viral infections in ruminants, using immunofluorescence. State Vet J 42:41-47

Emikpe BO, Jarikre TA, Akpavie SO, Opoku-Agyemang T, Asare D, Folitse RD (2019) Histological and immunohistochemical assessments of pneumonia in sheep slaughtered at Ibadan, Nigeria and Kumasi, Ghana. J Immunoass Immunochem 40:300-313. https:// doi.org/10.1080/15321819.2019.1589495

Forghani B (2010) Diagnosis by viral antigen detection. In: Jerome KR (ed) Lennette's laboratory diagnosis of viral infections, 4th edn. Informa Healthcare, New York, London, pp 113-132

Gafer JAM, Hussein HA, Reda IM (2009) Isolation and characterization of PI-3 virus from sheep and goats. Int J Virol 5:28-35

Grubor B, Gallup JM, Meyerholz DK, Crouch EC, Evans RB, Brogden KA, Lehmkuhl HD, Ackermann MR (2004) Enhanced surfactant protein and defensin mRNA levels and viral replication during parainfluenza virus type 3 pneumonia in neonatal lambs. Clin Diagn Lab Immunol 11:599-607

Haines DM, Chelack BJ (1991) Technical considerations for developing enzyme immunohistochemical stainingprocedures on formalinfixed parafin-embedded tissues for diagnostic pathology. J Vet Diagn Investig 3:101-112

Hala F, Fadel N, El-Shorbagy M (2009) Bacteriological and pathological studies on the causes of mortalities among sheep in SharkiaGovernorate farms. J Egypt Com Path Clinic 22:130-146

Hashemnia M, Chalechale A, Malmir E (2019) Pulmonary lesions in slaughtered sheep in Western Iran: gross and histopathological findings. Vet Ital 55:47-56. https://doi.org/10.12834/VetIt.785.3795.3

Intisar KS, Ali YH, Khalafalla AI, Rahman MEA, Amin AS (2010) Respiratory infection of camels associated with parainfluenza virus 3 in Sudan. J Virol Methods 163:82-86

Kahrs RF (1981) Parainfluenza 3. In: Kahrs RF (ed) Viral disease of cattle. Iowa State University Press, Ames, Iowa, pp 171-181

Kamdi B, Singh R, Singh V, Singh S, Kumar P, Singh KP, George N, Dhama K (2020) Immunofluorescence and molecular diagnosis of bovine respiratory syncytial virus and bovine parainfluenza virus in the naturally infected young cattle and buffaloes from India. Microb Pathog 145:104165. https://doi.org/10.1016/j.micpath.2020.104165

Kassahun A, Mersha C (2013) Study on the prevalence and pathological features of lung worm of sheep In Bahir Dar, Ethiopia. Acta Parasitol Global 4:41-48

Kayoueche F Z (2009) Epidemiology of hydatidosis and fascioliasis in animals and humans in Eastern Algeria. PhD. thesis. Mentouri University, Constantine, Algeria. 155 pp.

Kumar A, Kumar M, Varshney R, Nair KC, Lakkawar MG, Sridhar AW, Palanivelu M (2014) Pathomorphological studies of lung lesions in sheep. Indian J Vet Pathol 38:75-81

Lacasta D, Ferrer LM, Ramos JJ, Gonzalez JM, De las Heras M (2008) Influence of climatic factors on the development of pneumonia in lambs. Small Rumin Res 80:28-32. https://doi.org/10.1016/j. smallrumres.2008.08.004

Lehmkuhl HD, Cutlip RC, Bolin SR, Brogden KA (1985) Seroepidemiologic survey for antibodies to selected viruses in the respiratory tract of lambs. Am J Vet Res 46:2601-2604

Lindstrom L, Tauni FA, Vargmar K (2018) Bronchopneumonia in Swedish lambs: a study of pathological changes and bacteriological agents. Acta Vet Scand 60:54. https://doi.org/10.1186/s13028-018-0409-1

Lopez A, Martinson SA (2017) Respiratory system, mediastinum, and pleurae. In: Zachary JF (ed) Pathologic basis of veterinary disease, 6th edn. St. Louis, Missouri, Elsevier, pp 471-560

Luna L (1968) Manual of histology, staining methods of armed forces, institute of pathology, 3rd edn. McGraw-Hill Book, co, New York. pp 258.

Mahdi AA, Al-Naqshabendy AA, Haddel BT (2015) A study of some pathological lesions in the lung of sheep and duhok abattoir. Bas $\mathrm{J}$ Vet Res 14(2)

Martin WB (1996) Respiratory infections of sheep. Comp Immunol Microbiol Infect Dis 19:171-179. https://doi.org/10.1016/01479571(96)00002-1

Mekibib B, Mikir T, Fekadu A, Abebe R (2019) Prevalence of pneumonia in sheep and goats slaughtered at Elfora Bishoftu export abattoir, Ethiopia. J Vet Med. https://doi.org/10.1155/2019/5169040

Mishra S, Kumar P, George N, Singh R, Singh V, Singh R (2018) Survey of lung affections in sheep and goats: a slaughterhouse study. J Entomol Zool Stud 6:118-120

Mohamed R, Abdelsalam E (2008) A Review of pneumonic pasteurellosis (respiratory mannheimiosis) with emphasis on pathogenesis, virulence mechanism and predisposing factors. Bulg J Vet Med 11:139-160

Mugale M, Balachandran C (2019) An abattoir based histopathological survey of pulmonary pathology in small ruminants. Int J Livest Res 9:335-341. https://doi.org/10.5455/ijlr.20180903073626

Neamat-Allah ANF, Ali AA, Mahmoud EA (2020) Jeopardy of Lyssavirus infection in relation to hemato-biochemical parameters and diagnostic markers of cerebrospinal fluid in rabid calves. Comp Clin Pathol 29: 553-560. https://doi.org/10.1007/s00580-020-03094-z

Noori YM, Intisar KS, Nada EM, Ali YH (2014) Detection and isolation of bovine parainfluenza virus type 3 (PIV-3) in cattle in North Kordofan State, Sudan. IJASVM 15(1):70-78

Singh R, Kumar P, Sahoo M, Bind RB, Kumar MA, Das T, Kumari S, Kasyap G, Yadav JP, Saminatham M, Singh KP, Singh R (2017) Spontaneously occurring lung lesions in sheep and goats. Indian $\mathrm{J}$ Vet Pathol 41:18-24

Singh R, Singh S, Singh R, Varshney R, Dhama K, Kumari S, Singh KP, Dar JA, Kashyap G, Kamdi B, Kumar P, Singh V (2018) PathoEpidemiological study of jaagsiekte sheep retrovirus infection in the sheep and goats population, India. Biol Rhythm Res 51(8):11821196. https://doi.org/10.1080/09291016.2018.1559422

Stevenson RG (1969) Immunofluorescence studies of parainfluenza 3 virus in the lungs of lambs. J Comp Pathol 79:483-490

Stevenson RG, Hore DE (1970) Comparative pathology of lambs and calves infected with parainfluenza virus type 3. J Comp Pathol 80:613-618

Underwood WJ, Blauwiekel R, Delano ML, Gillesby R, Mischler SA, Schoell A (2015) Biology and diseases of ruminants (sheep, goats, and cattle). In: Fox JG, Anderson LC, Otto G, Pritchett-Corning KR, Whary MT (eds) Laboratory animal medicine, 3rd edn. Academic Press, Oxford, United Kingdom, pp 623-694. https://doi.org/10. 1016/B978-0-12-409527-4.00015-8

Yener Z, Saglam YS, Timurkaan N, Ilhan F (2005) Immunohistochemical detection of parainfluenza type 3 virus antigens in paraffin sections of pneumonic caprine lungs. J Vet Med 54:268-271

Publisher's note Springer Nature remains neutral with regard to jurisdictional claims in published maps and institutional affiliations. 